\title{
A critical analysis of conflicts between herdsmen and farmers in Nigeria: Causes and socioreligious and political effects on national development
}

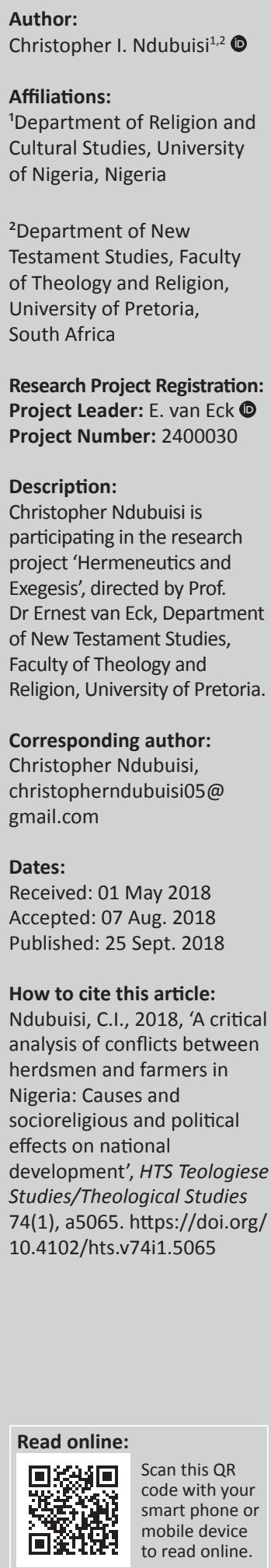

\begin{abstract}
The Fulani herdsmen attack on Nigerian citizens has taken on an alarming dimension this day. Hardly a week passes without one rumour of attack or another in one part of the country. In each of these attacks property worth millions of naira and lives are destroyed on a large scale. The huge human loss is the most worrisome of all. The objective of this study is to discuss the causes, as well as the socio-economic, political and religious implications of these attacks for sustainable development. The study adopted qualitative and phenomenological approaches in its investigation and analysis of data drawn from existing literature and oral interviews with selected individuals. The study discovered that many people have lost their property and lives; that many people have been displaced from their homes; and that the peace, security and unity of the country as a federation are being seriously threatened.
\end{abstract}

\section{Introduction}

The Fulani pastoralists appear to be greater in number than any other group in Nigeria that are involved in the business of animal rearing. They are the most prosperous. They make cattle meat affordable and readily available at the door post of Nigerians. Their animal meat constitutes a huge source of protein for the citizens. Hence they contribute substantially to the Nigerian economy. Eniola (2010:3 cited in Abbass 2014) opined that the Fulani indisputably represent a significant component of the Nigerian economy. They constitute the major breeders of cattle and the main source of meat, the most widely available and cheapest source of animal protein consumed by Nigerians. The Fulani own over $90 \%$ of the nation's livestock population, which accounts for onethird of the agricultural gross domestic product (GDP) and 3.2\% of the nation's GDP (Bello 2013).

Nonetheless, the frequent attacks on the farmers and citizens of Nigeria these days by the herdsmen is terribly alarming. Attesting to this fact, Adetula (2016) avers that previously the herdsmen were known to wreak havoc in certain communities in Nigeria, but now the rate at which they are committing these crimes has increased exponentially. This threatens the peace, security and unity of the nation as one geographical entity and will retard growth and development in all spheres of people's lives.

This negative attitude tends to negate their huge economic contribution to the gross national product (GNP). The aims of this study are as follows: to discuss the causes and socio-economic, religious and political implications of these attacks for national development and to suggest possible solutions to this malady. The study adopted qualitative and phenomenological approaches in its investigation and analysis of data. The work attempts to examine various areas in Nigeria where the herders unleash mayhem on the people.

\section{Theoretical and conceptual framework}

It is necessary to understand the basic concepts of the words 'conflict' and 'pastoralism' before exploring the extensive areas of conflict between pastoralists and farmers in Nigeria. Conflict is a reality. It does not exist in a vacuum or up there in the blues but among human beings. It is unavoidable in human interactions. However, violent or armed conflict can be avoided. Conflict is simply a disagreement. However, when the disagreement is not properly managed it degenerates into violent or armed conflict, which is physical war that involves the use of weapons like guns, spears, daggers, bows and arrows, as well as other sophisticated weapons. It is the desire to undo or cheat a person, individuals, groups, states or nations that leads to conflict or violent conflict, as the case may be.

Copyright: @ 2018. The Authors. Licensee: AOSIS. This work is licensed under the Creative Commons Attribution License. 
'Conflict' has been defined variously by different scholars under different ideological, historical and cultural influences. However, Francis (2007:20) defines conflict as the 'pursuit of incompatible interests and goals by different groups'.

Pastoralism is an aspect of agriculture that has to do with the rearing of animals like goats, sheep, cattle and so on. This is done by different people around the world, including the Fulani people. Fulani herdsmen are seen more in the Sahel region of Africa. Another account describes pastoralism as a way of life based primarily on raising livestock, particularly small ruminants, cattle and camels. Pastoral livestock production systems are mostly found in Africa's vast arid and semi-arid areas. These areas are characterised by marked rainfall variability and associated uncertainties in the spatial and temporal distribution of water resources and grazing for animals.

\section{National development}

According to Tolu and Abe (2011:238), national development is the 'the overall development or a collective socio-economic, political as well as religious advancement of a country or nation'.

\section{Methods of data collection and analysis}

Data for this study were collected using both primary and secondary sources. The primary sources include oral interviews that were collected through face-to-face interaction with the interviewees, which were aimed at eliciting firsthand information on their knowledge of the subject matter (see Table 1). The interview schedule specifically targeted people with rich knowledge of the issue under investigation. Such people included farmers, indigenes of the affected places, cattle rearers, scholars and so on.

The secondary sources included library materials such as textbooks, journal articles, encyclopaedias, newspapers, magazines, periodicals, reports and Internet materials. These materials helped the researchers to make a qualitative analysis of the issues involved in the topic.

\begin{tabular}{lllcl}
\multicolumn{5}{l}{ TABLE 1: List of oral interviews. } \\
\hline S/n & Name of interviewee & Occupation & App. age & Date of interview \\
\hline 1 & Mr. Eme Okechukwu & Lecturer & 41 & $05 / 04 / 2017$ \\
\hline 2 & Dr. Ngwu Elias & Lecturer & 40 & $05 / 04 / 2017$ \\
3 & Mr. Odo Damian & Lecturer & 32 & $05 / 04 / 2017$ \\
4 & Mr. Uwaegbute Kingsley & Lecturer & 33 & $05 / 04 / 2017$ \\
\hline 5 & Mrs. Ibenwa, Ebele .N. & Teacher & 49 & $10 / 03 / 2017$ \\
6 & Mr. Anizoba Emmanuel.C. & Lecturer & 45 & $05 / 03 / 2017$ \\
7 & Dr. Mrs. Okoli Anuli .B & Lecturer & 53 & $07 / 03 / 2017$ \\
8 & Rev Dr. Eze Ekene & Lecturer & 45 & $07 / 03 / 2017$ \\
\hline 9 & Dr. Diara Benjamin & Sr. Lecturer & 55 & $27 / 03 / 2017$ \\
10 & Rev Dr Okwor Christopher & Lecturer & 44 & $02 / 03 / 2017$ \\
11 & Mrs. Chukwuma Gift & Lecturer & 35 & $02 / 03 / 2017$ \\
12 & Dr. Mrs.Nwaoga, C.T & Lecturer & 50 & $04 / 04 / 2017$ \\
13 & Dr. Obeta, M.C & Lecturer & 57 & $02 / 04 / 2017$ \\
14 & Rev. Ugwuobute, Caleb. O. & Priest & 40 & $29 / 03 / / 2017$ \\
15 & Dr. Uzuegbu Charity & Sir.Lecturer & 50 & $02 / 03 / 2017$ \\
\hline 16 & Uroko Favour. C & Lecturer & 28 & $04 / 03 / 2017$ \\
17 & Ukeachism Precious & Lecturer & 30 & $07 / 03 / 2017$ \\
\hline & & & &
\end{tabular}

\section{Methods of data analysis}

The study adopted qualitative and phenomenological methods in the analysis of data so collected. The qualitative method enabled the researcher to make valid deductions from the secondary data while the phenomenological method helped the researcher to make more objective analysis of both the secondary and primary data sources as they relate to the attitudes of the herdsmen towards the farmers by allowing them to speak for themselves without any influence, bias or prejudice from the researcher.

Concretely, the causes and effects of the attacks by the herdsmen on national development were analysed. Consequently, the evidence of attacks by the Fulani herdsmen on the farmers and other citizens in different parts of Nigeria were identified. At the end, suggestions that will make for a healthier relationship between the herdsmen and the farmers were made.

\section{Antecedents of Fulani herdsmen in Nigeria}

In January 2013, Fulani herdsmen attacked some villages in Nasarawa State, killing 10 people and displacing over 5000 people. In a fresh attack on some villages in Nasarawa State, about 33 people were killed in November 2014 (http:// naijagist.com/Fulani-gunmen-attack). More attacks by the armed Fulani herdsmen came in 2016. Duru (2016) reports a gruesome attack on Agatu Local Government Area of Benue State in February 2016 in which about 7000 people were driven from six villages by the Fulani herdsmen. The villagers observed that despite heavy gunshots by the herdsmen, no military or security presence was felt. Over 200 persons were killed and houses were razed. In April 2016 there was a renewed attack on Agatu by the armed herdsmen. Statistics from the Benue State Emergency Management Agency indicates that no fewer than 30 persons died in the renewed violence.

Mamah et al. (2016) reveal that e Fulani herdsmen in Enugu State in April 2016. The herdsmen attacked Ukpabi Nimbo in Uzo-Uwani Local Government Area on 25 April 2016, killing over 40 people. Survivors fled to neighbouring communities. Two days after the Ukpabi Nimbo attack, there was another attack by the Fulani herdsmen in Umuchigbo community in Enugu East Local Government Area of Enugu State. It is clear that the deadly escapades of arms-bearing herdsmen are becoming increasingly unsettling. They have left their footprints in virtually every part of the country. In their last outings, they have been very unsparing of the communities (Ede 2016:25-26).

Militants from the Fulani ethnic group are believed to have killed at least 1229 people in Nigeria in 2014, according to the latest Global Terrorism Index, which ranked African nations as the world's third most terrorised countries. The Fulani militants, together with the terror group Boko Haram, were responsible for more than 7000 deaths that occurred in Nigeria in 2014. While Boko Haram is predominant in the news related to terrorism in Nigeria, little is known about the attacks and abductions by the Fulani herdsmen (Ludovica 2015). 
Adetula (2016) says that according to statistics provided by the Institute for Economics and Peace, 1229 people were killed in 2014, up from 63 in 2013, and Benue State seems to be the hardest hit in recent times. Barely 5 days before the end of Governor Gabriel Suswam's administration in May 2015, over 100 farmers and their family members were reportedly massacred in villages and refugee camps located in the Ukura, Per, Gafa and Tse-Gusa areas of the state. According to reports, in July 2015, suspected herdsmen attacked Adeke, a community on the outskirts of the state capital, Makurdi. In December 2015, 6 persons were killed at Idele village in the Oju Local Government Area. A reprisal attack by youths in the community saw 3 Fulani herdsmen killed and beheaded.

In February 2016, as a result of a clash between herdsmen and farmers in Benue State, 40 more people were killed, about 2000 displaced and not less than 100 were seriously injured (Duru 2016). Most recently, more than 92 Nigerians were massacred by suspected Fulani herdsmen in Benue and Niger States. Also, before this time, there were reported attacks by the Fulani pastoralists in the southern states of the country, including Enugu, Ekiti and Ondo States.

The Igbo Youth Movement, IYM, has lamented that Fulani herdsmen have killed 710 other Nigerians, excluding the 48 Agatu people in Benue State in the last 10 months, without the federal government addressing the issue. The statement signed by the founder of the IYM and leader of the South-East Democratic Coalition, Evangelist Elliot Uko, entitled, 'Ten Months of Carnage', read: 'Between June 2015 and April 2016, Fulani herdsmen have killed over 710 Nigerians (excluding [the] Agatu incident) in 48 recorded incidents, the highest in recent years' (Emeka \& Clifford 2016).

Another deadly attack was that of the 2016 southern Kaduna massacre, which some non-governmental organisations (NGOs) have labelled as genocide against southern Kaduna indigenes. Ajijah (2016) relates that the Catholic Archdiocese of Kafanchan says that the unrest in southern Kaduna State has claimed 808 lives. Moreover, 53 villages have so far been attacked and 57 people injured, according to the church. Governor Nasir El Rufai said the attackers were foreign Fulani herdsmen, who were avenging past attacks on them and their livestock. Mr Yakubu said 4 local government areas have been attacked, with 808 people killed and 1422 houses, 16 churches, 19 shops and one primary school destroyed (Ajijah 2016).

However, the Miyetti Allah Cattle Breeders Association, the umbrella organisation of herdsmen, notes that it has lost no fewer than 6000 cows to the crisis in southern Kaduna (cited in Ibenwa \& Uroko 2017:7). Garba (2017) reports that the National Emergency Management Agency said that 204 people have been killed in the southern Kaduna crises. Moreover, the clashes between Fulani herdsmen and locals in southern Kaduna have lasted for months.
The latest now is an attack on farmers and other people living in Jos, Plateau State, on Saturday 24 June, at 11 pm by Fulani herdsmen. Most Nigerians described the incident as most painful and deeply regrettable. News agent Idegu (2018:37) reports that no fewer than 86 persons were killed that weekend when gunmen suspected to be Fulani herdsmen attacked many communities in Plateau State. Police Spokesman Terna Tyopev, who confirmed the figure, said 8 persons were hospitalised and about 50 houses were razed. He added that 6 suspects were arrested. Yusuf also reports that Berom Villages - Xland, Gindin Akwati, Kura Falls, Nghar and Ruku - were completely sacked (p. 37). However, more people might have died because many families buried their dead before the police arrived. Tyopev added that some bodies were deposited at the Jos University Teaching Hospital mortuary and security had been tightened in the affected villages to restore peace.

On Tuesday, 26 June, while I was listening to the newscast, Nigerian Television Authority International reported in its 9 pm news that over 200 people had been killed in the conflict between the Fulani herdsmen and farmers in Jos, Plateau State, on Saturday, 24 June, and that this was the highest death toll so far in the history of conflict between the Fulani and farmers.

\section{Causes of conflict between Fulani herdsmen and farmers}

Some factors have been considered to be responsible for many of the conflicts that happen between the farmers and Fulani herdsmen in Nigeria. The factors are stated as follows.

Firstly, unauthorised encroachment into farmlands have led to serious conflicts between the farmers and herdsmen in recent times, because of the damage they cause to crops and fallow lands left to replenish the nutrients after long years of use. The herdsmen's cows often stray into the farmlands of the farmers without permission and destroy crop nurseries or full-grown crops, which they hope to harvest and sell in the near future. This attitude, no doubt, provokes the farmers to go after their animals (according to Eme Okechukwu and Dr Ngwu Elias in a face-to-face interview on 05 April 2017). Okoli and Atelhe (2014:80) reveal that the shrinking of ecological space and resorts creates an atmosphere of ecoscarcity, which raises the stakes and puts a premium on the available resources. What usually results from this is fierce competition and a desperate struggle for subsistence. In this context, therefore, conflict not only becomes inevitable; it simply becomes a matter of survival.

Secondly, the Fulani herdsmen use other people to buy land for them in their own name while they lie to the natives that they are people buying the land for one business or the other. However, the owners of the land discover later that they have been tricked by the herdsmen when they see the land being used by herdsmen for cattle business, contrary to their will; this leads to conflicts (Odo Damian and Uwaegbute Kingsley in an interview on 05 April 2017). 
Thirdly, climate change is one of the major causes of conflicts between farmers and herdsmen. This is so because when there is unfavourable weather the herdsmen will be compelled to leave their original habitation to another area for greener pastures. Lending support to this, Gleick (2010:331-332) says that climate change has been tipped as the greatest single factor to induce migration and population displacement. According to the Intergovernmental Panel on Climate Change, this will affect people displaced by shoreline erosion, coastal flooding and agricultural disruption. According to Ibenwa, Nwokocha and Okoli (2017:290), migration is the movement of people from one geographical region to another for the purpose of taking up permanent or semipermanent residence.

Fourthly, lack of political will by the government to arrest and punish the offenders adequately is one of the factors fuelling the activities of the herdsmen in Nigeria today. A case in point was what happened in Nimbo in Uzo-Uwani Local Government Area and in Enugu town in 2016, all in Enugu State. The Fulani herdsmen attacked farmers at Nimbo because of a misunderstanding over grazing fields and killed over 50 persons and destroyed their property, worth thousands of naira (Mamah et al. 2016). From that time to the present no serious arrest has been made and the Fulani come back at intervals to attack famers and villagers on their farms. A few months after the attack at Nimbo and Enugu, Fulani herdsmen entered a farm to feed their flocks and while they were doing that the owners of the farm land came and chased them and their cattle away. Sequel to this, at midnight the Fulani herdsmen came and attacked the people, killing a pregnant woman.

Fifthly, the inability of government in most cases to respond quickly to distress calls and early warning signs is an issue that promotes conflict. This negative attitude has made it difficult to stop crises that would have been prevented if government had responded accordingly to distress calls and warnings.

\section{Negative effects on national development}

The effects of the Fulani herdsmen's activities cannot be overemphasised. Hereunder they are enumerated.

\section{Economic effect}

It is an indisputable fact that the activities of the Fulani herdsmen against the farmers have resulted in a huge economic setback in Nigeria today. Some of these setbacks are discussed here below.

Creation of artificial scarcity: From what we know, anytime farmers are attacked they will run away from their farmlands and find it difficult to return for fear of being attacked again. This sometimes lasts for a long time, thereby hindering sowing and reaping. This undoubtedly creates an artificial scarcity of goods and services. In line with this, Ebele N. Ibenwa (personal communication on 10 March 2017) expressed that the Fulani's frequent attacks on the farmers have led to the creation of an artificial scarcity of goods and services and, consequently, to inflation and devaluation of the naira. To buttress her point further, she cited the Zaki-biam Yam Market attack in Benue State that happened on 20 March 2017, in which over 50 people were killed, and out of fear the traders refused to come back to the market for a long time. This created a man-made scarcity, which ordinarily would have been avoided if the Fulani herdsmen's attack on the farmers and villagers had not happened.

Inflation and devaluation of the naira: Inflation, simply put, is a persistent increase in the prices of goods and services over a period of time. Anyanwuocha (1996:25) defines it as a persistent rise in the general price level. The artificial scarcity created by the frequent attacks of the herdsmen on citizens as stated earlier leads to inflation, which in turn leads to devaluation of the naira. Ebele N. Ibenwa and Emmanuel C. Anizoba, in a personal communication with the researcher on 05 March 2017, with this viewpoint, argued that the money is devalued because much money is now chasing few goods and services. The money cannot buy as much quantity as it could before.

There is a decrease in output per capita, because of restrictions on people's movements as a result of curfews. Moreover, the daily output in goods and services is seriously affected. People can no longer move to their farms, shops and business centres freely as they wish. Lending credence to this view Ebele N. Ibenwa and Emmanuel C. Anizoba, in a personal communication on 05 March 2017, averred that the overall output of the people was decreased because of the check placed on the people.

Discouragement of foreign investment: The incessant attacks by the Fulani herdsmen scare away foreigners who have come to Nigeria to do business. In the course of the attacks, lives and property, public companies, film-producing houses and industries are destroyed. When foreigners see these things happen, they get discouraged and withdraw their businesses and go back to their countries (Ibenwa 2012).

Creation of refugees and internally displaced people (IDPs): Anytime there is any serious attack on the citizens, houses are burnt down and people are rendered homeless. Consequently, some of them who are not well-to-do cannot easily find themselves a home and, therefore, they are quartered in public buildings as IDPs. Okoli and Eze noted that war creates refugees and large numbers of people are displaced, which are popularly known as IDPs. People are displaced from their houses as a result of arson by the Fulani herdsmen and they camp in public buildings (oral interview with Anuli B. Okoli and Eze Ekene, 07 March 2017).

\section{Political effects}

Politically, it makes for distraction in government programmes and a waste of time. Whenever there is a violent attack by the herdsmen, government attention is required. It 
leaves whatever it is doing to address the herdsmen issue and spends time addressing it. Uwaegbute amd Diara, lending credence to this viewpoint, said that government is truly distracted in times of crisis of this sort (personal interaction with Uwaegbute Kingsley and Dr Diara Benjamin, 27 March 2017).

Extra financial burden on the government: In a very serious attack the government is required to provide relief materials like foodstuffs, clothes and medicines, to mention but a few, for victims of the attacks. This view was upheld by Nwaoga and Eme (Chinyere T. Nwaoga and Okechukwu Eme, in a personal communication on 04 April 2017), when they quipped that government spends a huge amount of money in taking care of the victims of war, and sometimes this calls for a supplementary budget.

\section{Educational effects}

Educational effects: These activities lead to closure of primary and secondary schools and tertiary institutions. When the schools are closed the school timetable of events is adjusted, thereby prolonging the students' duration of study (interaction with Dr Obeta and Okechukwu Eme, 02 April 2017).

\section{Social effects}

Increased unemployment gap: Because companies, films and industries are destroyed during such crises, it takes owners of these businesses time to rebuild their destroyed business centres. Their employees spend this long period without work to do. They add to the number of unemployed youths that are roaming our streets. Attesting to this fact, Dr Charity Uzuegbu and Dr Chinyere T. Nwaoga (oral interview on 02 March 2017) in their interactions with the researcher said that it was true of any war that involved the use of weapons.

Change in population size: People living in areas experiencing frequent Fulani herdsmen attacks usually relocate to areas not prone to attacks. This is what has been happening in southern Kaduna from the middle of 2016 to 2017. Dr Anuli Okoli and Favour Uroko on 04 March 2017, in separate interactions with the researcher, confirmed this to be true when they argued that many strangers have decided to move down to their homes, thereby decreasing the population of the people living in Kafanchan and increasing the population of the place they are relocating to.

Wanton destruction of lives and property: It is common knowledge that whenever herdsmen carry out an attack, people are killed in the tens, hundreds or thousands and property worth hundreds of naira is destroyed. To this end, Christopher Okwor and Gift Chukwuma, in their discussion with the author on 02 March 2017, averred that crisis or war leads to destruction of lives and property worth thousands of millions of naira and irreparable loss of human lives.

Increase in number of physically challenged people: During the pastoral attacks people are killed or maimed. Those who are maimed may no longer be able to do what they hitherto did themselves because of impairment. And they may resort to begging as a means of livelihood, thereby increasing the number of beggars on the streets of our towns and cities. In an oral interview with Dr Anuli B. Okoli and Precious Ukeachism (on 07 March 2017), they opined that war no doubt increases the number of physically challenged people in the society because of the use of offensive weapons during riots that give people deep cuts and all forms of deformities.

Restriction of movement or declaration of state of emergency: Most times when there is an attack, people's movements are restricted. In some cases the government may decide to declare hours of curfew or a dawn to dusk curfew. This is an infringement on the statutory freedom of movement of the citizen. In a personal communication on 05 April 2017, Damian Odo and Dr Elias Ngwu stressed the fact that whenever there is any serious attack on citizens by any grieved group, whether it is a religious sect, Fulani herdsmen, an ethnic group or political group, the government usually declares a state of emergency or curfew. When this happens, people's movements are restricted

\section{Religious effects}

The herdsmen's conflict, like other conflicts in Nigeria, such as the Maitatsine religious conflict, OIC conflict, Sharia conflict and Boko-Haram terroristic activity, have adversely affected religious activities such as night vigils, midweek services, Sunday services and open-field crusade, particularly night vigils, which Ugwuobute believed was one of the most powerful means of attacking Satan, evil spirits, witches and wizards and occult men and women (personal communication with Caleb Ugwuobute, 29 March 2017).

\section{Recommendations}

Based on the discussions in this work, the researcher makes the following recommendations:

There should be legislation guiding the activity and the relationships of the Fulani herdsmen with farmers and other Nigerian citizens at large. The rule of law should be applied to all defaulters, that is to say that there should be no sacred cow. Furthermore, there is need for change of behaviour. We may have to learn to accommodate, open up to divergent views, with the view to finding common ground that may end up preserving the unity of the people.

Another national conference is seriously advocated. The Fulani herdsmen should be ordered by government to surrender the guns and live ammunition in their possession to government. Thereafter, they should be banned from carrying such weapons. This, no doubt, will help to stop cases of nefarious activities like highway robbery, kidnapping and indiscriminate killings in which they engage these days. The government should be more proactive in their action rather than being reactive. Government's quick response to early signs and warnings of impending crisis is highly advocated. 


\section{Results and conclusion}

It was discovered during the course of the research that many people have lost their lives and property, and an even greater number have been displaced from their homes. The displaced people have, therefore, become refugees in their homeland. Their activity has hindered meaningful development in Nigeria. Consequently, the peace, security and unity of the country as a federation are under serious threat.

\section{Acknowledgements Competing interests}

The author declares that he or she has no financial or personal relationships which may have inappropriately influenced him or her in writing this article.

\section{References}

Adetula, D., 2016, Understanding the Fulani herdsmen crisis in Nigeria: Here is everything you need to know, viewed 28 January 2018, from http://venturesafrica.com/ understanding-the-fulani-herdsmen-crisis-in-nigeria-what-you-need-to-know

Ajijah, A., 2016, 'Church says 808 killed in southern Kaduna', December 29, viewed n.d., from https://www.premiumtimesng.com/news/top-news/219173-churchsays-808-killed-southern-kaduna.html

Anyanwuocha, R.A.I., 1996, Fundamentals of economics for senior secondary schools, Africana-Feb Publishers Limited, Onitsha.

Bello, A.U., 2013, 'Herdsmen and farmers conflicts in North-Eastern Nigeria: Causes, repercussions and resolutions', Academic Journal of Interdisciplinary Studies 2(5) 129. https://doi.org/10.17570/stj.2015.v1n2.a13

Duru, P., 2016, '7000 persons displace in Fulani herdsmen, Agatu farmers clash in Benue,' Vanguard Newspaper, February 29.

Ede, V.I., 2016, 'Christian religious response to the plights of the internally displaced persons in Nigeria', PhD thesis presented to the Department of Religion and Cultural Studies, University of Nigeria, Nsukka.
Emeka, M. \& Clifford, N., 2016, '710 Nigerians killed by Fulani herdsmen in 10 months Igbo Youth Movement', Vanguard News, 27 April, p. 1.

Abbass, I.M., 2014. 'No retreat, no surrender conflict for survival between Fulani pastoralists and farmers in Northern Nigeria', European Scientific Journal 8, 1.

Francis, D.J., 2007, 'Peace and conflict studies: An African overview of basic concepts', in S. Gaya-Best (ed.), Introduction to peace and conflict studies in West Africa, pp. 20-27, Spectrum Books Limited, Ibadan.

Garba, M., 2017, Nigerian govt. says 204 killed in Southern Kaduna crisis, viewed 28 January 2018, from http://www.trezzyhelm.com/2016/12/more-graphic-photosfrom-fulani.html?m=1

Gleick, P.H., 2010, Water, drought, climate change, and conflict in Syria, American Meterological Society, Washington.

Ibenwa, C.N., 2012, 'Fanaticism and religious riots in Northern Nigeria: Its implications for societal development', A PhD thesis submitted to the Department of Religion and Cultural Studies, University of Nigeria, Nsukka.

Ibenwa, C.N, Nwokocha, V.C. \& Okoli, A.B., 2017, 'Gsp, climate change and eschatological events', in A.A. Nwosu (ed.), A pre-conference proceeding for the 2017 school of general studies international conference held at University of Nigeria, Nsukka, May 7-10th, Grand-Heritage Global Communications, Nsukka, p. 290.

Ibenwa, C.N. \& Uroko, F.C., 2017, 'The ehno-religious conflicts in Southern Kaduna of Nigeria: Causes and implication for national development', A paper presented at the international conference of the society for research and academic excellence, University of Nigeria, Nsukka, 6-9th February,pp.8-9.

Idegu, Y.A., 2018, 'Curfew in plateau as herdsmen kill 86: Fulani we have lost 300 cows', The Nation Newspaper, Lagos, Vintage Press Limited, Monday 25 June, 2018, p. 37.

Ludovica, I., 2015, 'Nigeria Fulani militants: Herdsmen accused of killing 1,200 people in 2014', viewed 28 January 2018 , from http://www.ibtimes.co.uk/nigeria-fulanimilitants-herdsmen-accused-killing-1200-people-2014-1530042

Mamah, E., Ndujihe, C., Nkwopara, C. \& Ozor, C., 2016, 'Bloodbath in Enugu as Fulani herdsmen kill 40,' April 26.

Mkutu, K., n.d., Pastoral and conflict in the horn of Africa, Africa Peace Forum, University of Bradford, Bradford.

Okeke, C.O. \& Ibenwa, C.N., 2017, 'The Igbo example of conflicts between African traditional religion and Christianity in Eastern Nigeria', Unpublished article.

Okoli, A.C. \& Atelhe, G.A., 2014, 'Nomads against natives: A political ecology of herder/farmer conflicts in Nasarawa state, Nigeria', American International Journal of Contemporary Research 4(2), 76-88.

Tolu, L. \& Abe, O., 2011, 'National development in Nigeria: Issues, challenges and prospects', Journal of Public Administration and Policy Research 3(9), 237-241. 